\title{
THE HISTORY OF THE ELEPHANT SEAL INDUSTRY AT MACQUARIE ISLAND AND AN ESTIMATE OF THE PRE-SEALING NUMBERS
}

\author{
by Mark A. Hindell and Harry R. Burton
}

(with two tables and four text-figures)

HINDELL, M.A. \& BURTON, H.R., 1988 (viii): The history of the elephant seal industry at Macquarie Island and an estimate of the pre-sealing numbers. Pap. Prøc. R. Soc. Tasm., 122(1): 159-176. Paper presented at the Macquarie Island Symposium, Hobart, May 1987. https://doi.org/10.26749/rstpp.122.1.159

ISSN 0080-4703. Antarctic Division, Department of Science, Channel Highway, Kingston, Tasmania, Australia 7150 .

A comprehensive list was compiled of all sealing ships that visited Macquarie Island $\left(54^{\circ} 30^{\prime} \mathrm{S}, 158^{\circ} 57^{\prime} \mathrm{E}\right)$ between 1810 and 1919 and, where possible, their cargoes. Approximately 207 sealing visits were made to Macquarie Island in 109 years and an estimated 8380 tuns of elephant seal oil removed. The major sealing effort seems to have been in the first 20 years, between 1810 and I829, when almost half of the voyages occurred and over half of the oil was collected. For the present study, a mathematical model was devised to examine the responses of the population to the estimated annual harvest of seals from I810-29. Given the often incomplete nature of the sealing records, accurate estimates of the pre-sealing elephant seal population were impossible to obtain, but the model suggests that it may have been in the region of 93000 to 110000 animals. The major impact of sealing activity was between 1820 and 1830, when the population was reduced by approximately $70 \%$. Numbers are thought to have recovered to near pre-sealing levels by the 1900 's, when the level of sealing was within the sustainable yield of the population.

Key Words: elephant seal, sealing industry, sealing ships, Macquarie Island.

\section{INTRODUCTION}

Southern elephant seals (Mirounga leonina) have large deposits of blubber: a large male can have over $300 \mathrm{~kg}$ of blubber and females approximately $100 \mathrm{~kg}$ (Winter \& Nunn 1950, Bryden \& Stokes 1969, Gales \& Burton 1987). The blubber plays an important role in thermoregulation and energy storage (Bryden 1968). The blubber also has a very high proportion (around $84 \%$, Hamilton 1949) of oil of a particularly high quality, which had important industrial and commercial applications in the eighteenth, nineteenth and early twentieth centuries (Hamilton 1839, Scammon 1874).

The combination of large blubber deposits, high yield of quality oil and the relative ease of procuring and extracting it meant that the southern elephant seal was subjected to intense commercial harvesting at all its major breeding sites in the last century. The exploitation was so intense in some areas, such as in the islands of Bass Strait in southeastern Australia, that the species was completely exterminated. Macquarie Island $\left(54^{\circ} 30^{\prime} \mathrm{S}\right.$, $158^{\circ} 57^{\prime} \mathrm{E}$ ) is one of the major breeding sites of the elephant seal, and has approximately one-sixth of the world population of 600000 breeding there (McCann 1985). The population was exploited from the time of its discovery by sealers in 1810 until 1919 (Cumpston 1968). The extent of these activities and their impact on the population have not been documented, although generally assumed to have been severe (Carrick \& Ingham 1962a, Ling \& Bryden 1982).

This paper attempts to assess the extent and impact of the seal oil industry on the elephant seal population of Macquarie Island. Old sealing and shipping records were used to estimate the number of seals killed annually during the whole period of exploitation and a population model was devised to estimate the initial size of the Macquarie Island elephant seal population and to examine the responses of the population to the estimated levels of harvesting.

\section{METHODS}

Visits of Sealing Ships to Macquarie Island

A comprehensive list was compiled of all ships that visited Macquarie Island between 1810 and 1930, giving (a) the date and port of departure, (b) the date of arrival and departure at Macquarie Island, and (c) the date and port of return (Appendix 1). Cumpston (1968) was the principal source of information, although the details were 
checked and expanded through lists of shipping arrivals and departures from Sydney and Hobart (Cumpston 1963, Nicholsen 1963, 1983, 1985). The cargoes of the ships were also recorded where possible, but much of this information was incomp lete.

\section{Amount of Oil Removed}

The amount of oil removed in the unknown cargoes was assumed to equal the average oil tunnage of the known cargoes in that year; the cargoes were usually listed in tuns, gallons, barrels or casks. All of the results presented here are expressed as tuns; the following conversions (Rhys Richards, pers. comm.) were used where necessary: 1 tun $=252$ gallons $($ Kemp 1976) or 2.3 casks or 8 barrels ( 1 barrel $=31.5$ gallons).

Not all of the oil collected left the island. Small a mounts were used by the sealers for lighting and heating, and it was not uncommon for some to be lost during the hazardous loading procedures (Cumpston 1968). We have assumed an annual loss of $5 \%$, based largely on the few records of rafting losses in Cumpston (1968). Some ships also visited Campbell Island on the same voyage, but only 48 tuns of oil are known to have come from this source (Kerr 1976). It is also possible that some fur seal carcasses were rendered down for oil during the first few years of exploitation.

\section{Oil Yield Per Seal}

Several assumptions were needed to estimate how many elephant seals were killed to produce the oil tunnage collected at Macquarie Island. There are no records of the relative number of male and female seals taken. These are critical data, in view of the large size difference between males and females, and the very different effect on population replacement of harvesting males as opposed to females (see below).

Data on oil yield per seal have been reported anecdotally. Cumpston (1968) reported that bulls newly ashore at Macquarie Island yielded 0.5 tuns of oil, but this decreased to 0.33 tuns as the breeding season progressed. Females produced only 0.1 tuns. Busch (1985) estimated that 8.3 cows were needed to make up one tun of oil, or approximately 0.12 tuns of oil per seal, and he used this figure as a basis for calculating total elephant seal harvests around the world.

The most reliable information on oil yield comes from South Georgia, where there was an elephant seal industry operating periodically from the late 1700's through to 1964 (McCann 1980).
The industry became regulated in 1910 and records were kept subsequently of the number of seals killed and the annual oil harvest (Laws 1960). The average yield per seal increased from 1.15 to 2.01 barrels of oil per seal between 1910 and 1955, as the sealers improved their processing techniques (Laws 1960). Consequently, only the first ten years (i.e. 1910-20) of data from South Georgia were used, as the level of technology of blubber extraction at that time is likely to be similar to that used at Macquarie Island. These data were averaged to give 4.98 seals per tun of oil, or 0.2 tuns per seal. This represents approximately $180 \mathrm{~kg}$ of oil per seal, assuming a density of blubber of $0.95 \mathrm{gml}^{-1}$ (Gales \& Burton 1987), and $210 \mathrm{~kg}$ of blubber, assuming an $84 \%$ oil content in the blubber (Hamilton 1949). This agrees quite well with the mean blubber weight of $220 \mathrm{~kg}$ calculated from ten males at Heard Island (Gales \& Burton 1987). This figure was used as the average yield per male, assuming that the Macquarie Island sealers used similar techniques and that the seals were of similar sizes. Female elephant seals were assumed to yield one-third of this, or 0.07 tuns of oil ( $70 \mathrm{~kg}$ of blubber) per seal. It was further assumed that oil yield per seal did not change during the hundred-odd years of exploitation at Macquarie Island. In reality, it is likely that oil yield improved with the introduction of the coal-fired, high-pressure digesters in the last 30 or 40 years (Cumpston 1968).

\section{Population Model}

A model of an elephant seal population was devised to help estimate the initial size of the population prior to sealing. Population models have been used many times to describe other marine mammal populations and to assess the potential impact of exploitation (e.g. Allen \& Kirkwood 1978, Beddington \& Kirkwood 1980, Shaughnessy \& Best 1982). The most fundamental parameters that must be incorporated into any models are sex ratio at birth, longevity of each sex, survivorship and mortality of each age class, age at first breeding, pregnancy rate and population size. In the following model, all parameters except the pregnancy rate are density independent, that is, are not directly affected by the size of the population.

Data from Macquarie Island were used whenever possible, but when these were unavailable, data were taken from the population at South Georgia. The parameters selected were as follows:

(1) A sex ratio at birth of 54 males to 46 females was derived from Carrick et al. (1962) for the Macquarie Island population in the 1950's. 
(2) The age-specific natural mortalities rate adopted wascalculated by McCann (1985) for the population at South Georgia. We have not allowed for possible density-dependent effects on pup mortality. Although it has been reported that pup mortality increases in crowded harems (Carrick \& Ingham $1962 \mathrm{~b}$ ) there is no quantitative information to use as a basis in our model. Consequently, our model may tend to overestimate pup survivorship in large populations.

(3) Age at first parturition was taken to be four years (Carrick et al. 1962).

(4) Breeding age for males was assumed to be eight years. Males in an unexploited population usually do not take an active part in breeding unti they are at least ten years old (Carrick et al. 1962 Jones 1981), although they are physiologically capable at a much earlier age (Griffiths 1984). We have assumed that all males over eight years old are potential breeders that can replace older males removed by the sealers.

(5) An initial pregnancy rate was taken as $88 \%$ in a stable population (McCann 1985).

(6) A sex ratio among breeding adults of one male to twelve females (Carrick et al. 1962, Hindel \& Burton 1987) was used. It was assumed that the pregnancy rate of $88 \%$ would be achieved while this sex ratio was maintained. Once the surplus males were removed from the population and the number of active breeding males decreased, the pregnancy rate was also assumed to decrease, as there were now fewer males to mate with the females. The pregnancy rate was assumed to decrease linearly with the decrease in the number of males, once the surplus had been removed.

The model also assumed that the animals removed from the population by sealers were all of breeding age; it is possible that the sealers took juvenile seals, during their moulting haul-out in November and December, but for most other times of the year only adult animals are ashore. It is known that, during 1890-1919, the sealers changed their attentions from elephant seals to penguins with the end of the breeding season in November (Cumpston 1968). Other assumptions of the model were that the sealers took males first, only taking females when all of the accessible males were removed, that all the animals of breeding age and above were available to the sealers, and that the population was initially stable.

The number of animals in each age class for each sex was then calculated for a series of population sizes. The total number of breeding males and females and the number of surplus males which could be harvested without affecting that population was then calculated. For example, a population of 79369 seals would have 21000 females and 4401 males of breeding age and above. Of these $21000 / 12=1750$ males would be needed for breeding and 2651 males could be killed without affecting pup production.

The amount of oil collected in the first year of sealing was then introduced into the model, initially assuming that this consisted entirely of males. The model then faced a series of options:

(1) If the amount of oil taken represented fewer males than the surplus, the number of males taken was deducted from the total number of breeding males, and the next year's population structure calculated.

(2) If the amount of oil taken represented more than the surplus, but fewer than the total number of breeding males, then the number of males taken was deducted from the total number of breeding males and the new adult sex ratio calculated. Taking account of the reduced number of males, a new pregnancy rate and the next year's population structure were calculated.

(3) If the amount of oil collected represented more than the total number of breeding males, it was assumed that all of the males available that year were taken and that the remainder of the oil was made up from females. In these years, the pregnancy rate was assumed to be zero as no males were left to impregnate the females. The next year's population structure was then calculated.

(4) If the amount of oil collected was more than was represented by all of the breeding males plus all of the breeding females available in that year, this was taken as preemptive evidence that the initial population size was too small. The process was then repeated with a larger initial population size.

By using the model in this way, it was possible to estimate the minimum initial population that could have sustained the observed level of sealing between 1810 and 1829 .

\section{RESULTS}

\section{Sealing Activity Between 1810 and 1916}

There were six distinct phases in the exploitation of elephant seals at Macquarie Island (table l):

(1) the pre-sealing phase prior to 1810 ;

(2) the first sealing phase between 1810 and 1829, when 97 ships, or an average of five ships per year, visited the island;

(3) a "lapse" phase of 44 years between 1830 and 1874 , during which only three sealing ships called 


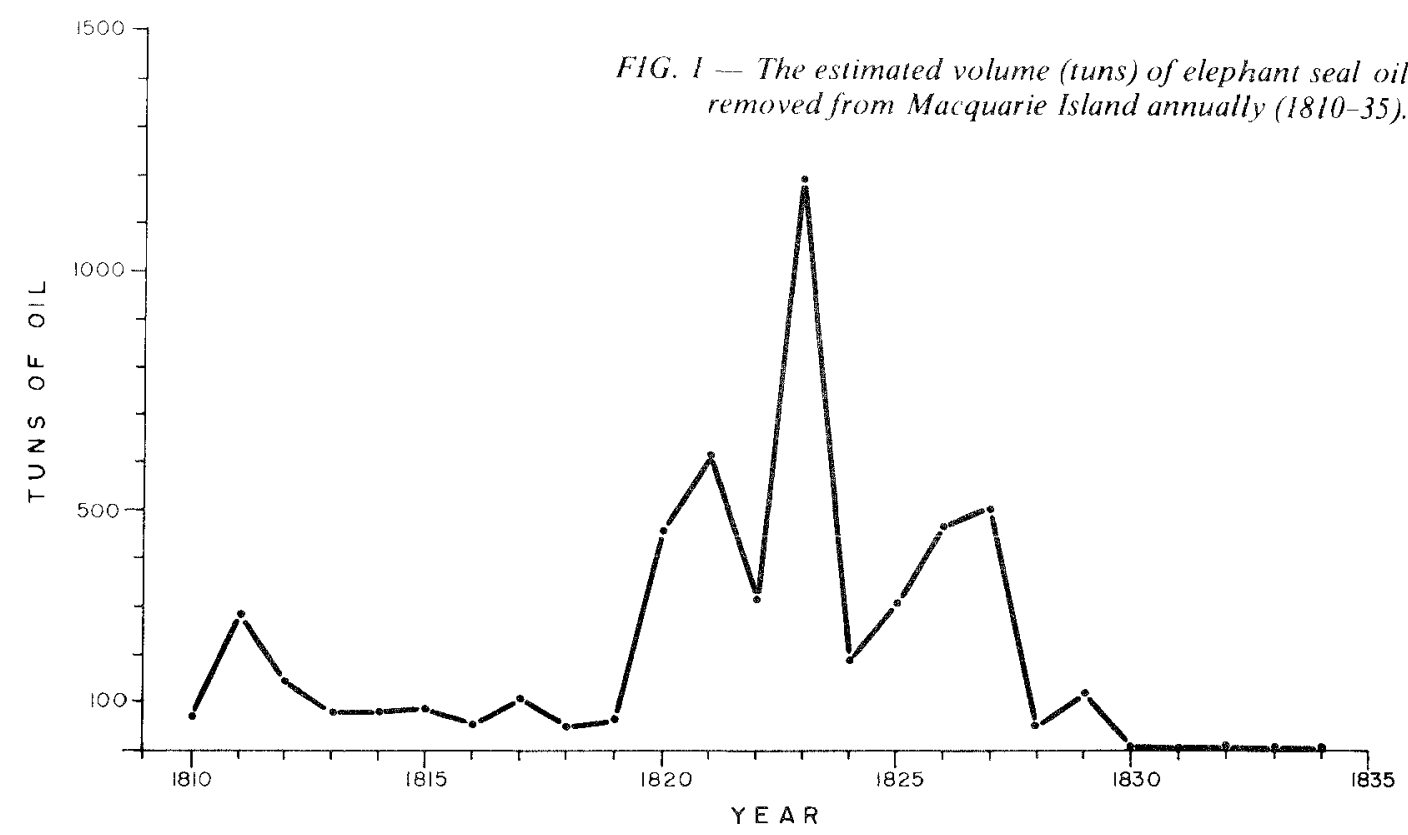

at the island, two in 1834 and one in 1851; several non-sealing ships visited the island during this time;

(4) the resumption of sealing activity between 1875 and 1889 , when 30 ships visited the island (an average of two ships per year);

(5) the "Hatch" years between 1890 and 1919, when Joseph Hatch had the exclusive rights to work Macquarie Island; 75 sealing voyages were made to the island during this time, an average of almost three ships per year;

(6) the recovery phase from 1919, when sealing stopped at Macquarie Island, to the present day, during which time the population has been commercially unexploited.

\section{TABLE 1}

The six phases in the history of elephant seal exploitation at Macquarie Island

\begin{tabular}{|c|c|c|c|c|c|c|c|}
\hline \multirow[t]{2}{*}{ Phase } & \multirow[t]{2}{*}{ Years } & \multicolumn{3}{|c|}{ Sealing Voyages } & \multicolumn{3}{|c|}{ Oil Removed (tuns)* } \\
\hline & & $\begin{array}{c}\text { Listed } \\
\text { Cargoes }\end{array}$ & $\begin{array}{l}\text { Unlisted } \\
\text { Cargoes }\end{array}$ & Total & $\begin{array}{c}\text { Listed } \\
\text { Cargoes }\end{array}$ & $\begin{array}{l}\text { Est. unlisted } \\
\text { Cargoes }\end{array}$ & $\underset{(+5 \%)^{* *}}{\text { Total }}$ \\
\hline 1 & $?-1810$ & 0 & 0 & 0 & 0 & 0 & 0 \\
\hline 2 & $1810-1829$ & 81 & 16 & 97 & 4400 & 869 & 5533 \\
\hline 3 & $1830-1874$ & 3 & 0 & 3 & 30 & 0 & 30 \\
\hline 4 & $1875-1889$ & 26 & 6 & 32 & 557 & 129 & 720 \\
\hline 5 & $1890-1919$ & 52 & 23 & 75 & 800 & 1200 & 2100 \\
\hline 6 & $1920-1985$ & 0 & 0 & 0 & & 0 & 0 \\
\hline
\end{tabular}

* Divided into known amount removed in the listed cargoes and the amount estimated to have been removed in the unlisted cargoes.

** Total estimated volume removed, including a 5\% correction for loss on the island. 


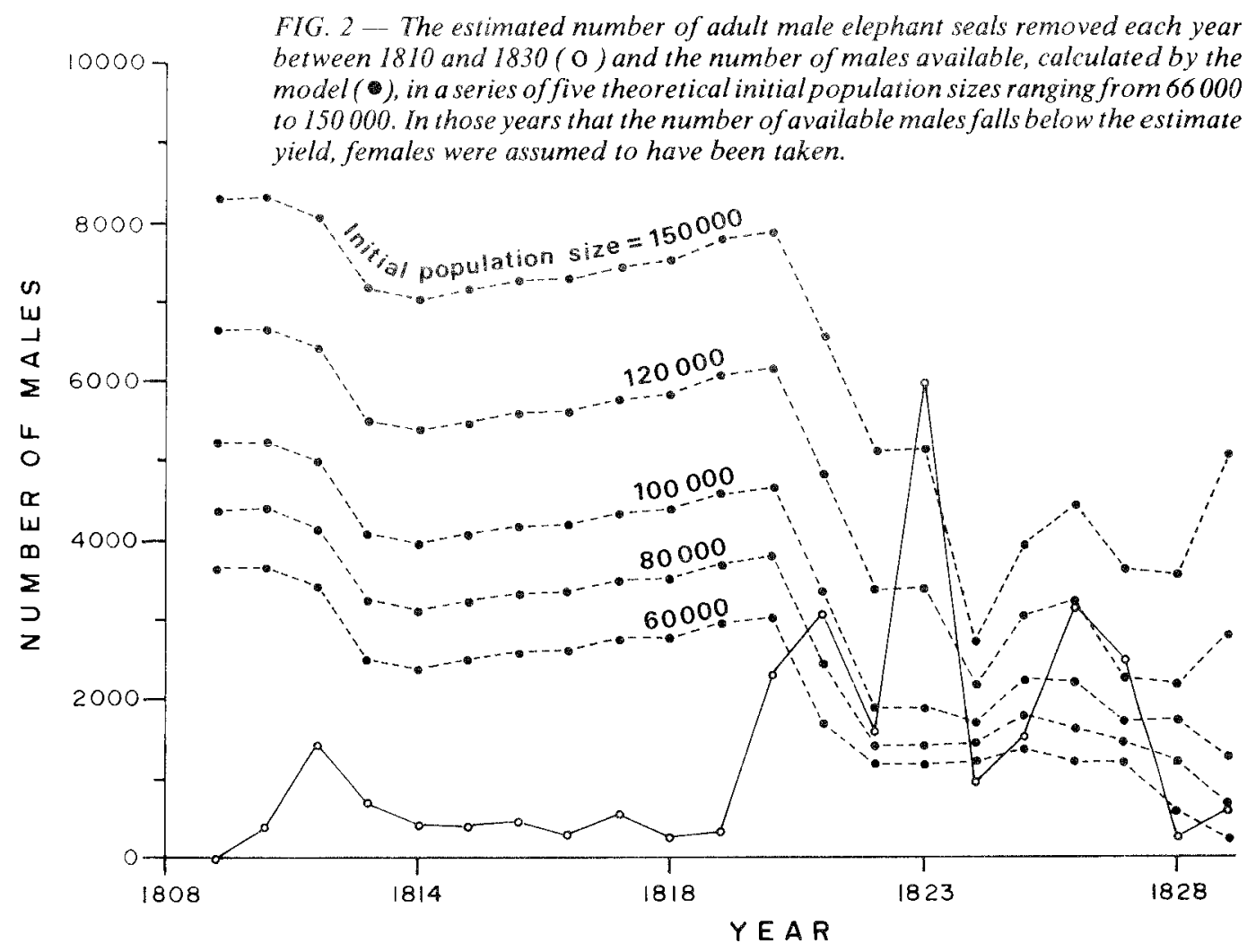

over the next seven years. During the lapse phase (1830-74), one tun of oil was collected from two visits in 1834 and 147 seals (yield approximately 129 tuns of oil) were reported to have been killed in 1851 , when only one call by a sealing ship is recorded. Sealing resumed in 1875, and 557 tuns of oil are known to have been removed in 26 voyages between then and 1889 . There were six ships (20\% of the voyages) with unlisted cargoes at this time. The total estimated volume of oil collected was 720 tuns.

The records of the amount of elephant seal oil removed from Macquarie Harbour are less complete from 1890. Gangs of sealers were usually deployed before the elephant seal breeding season, around August, and they would work the seals until most of the adult seals had left in mid- to late November. They then switched to taking penguins for the next two to three months until they too left the island in March. Often the two types of oil were not distinguishable in the cargo manifests. Approximately 3700 tuns of oil were removed from the island between 1890 and 1916 , of which 700 tuns are known to have been penguin oil and 800 tuns elephant seal oil. Assuming the remaining 2200 tuns of oil were composed of similar proportions of penguin to elephant seal oil, approximately 2000 tuns of elephant seal oil (or 2100 allowing for a $5 \%$ annual loss rate) were collected between 1890 and 1916 .

\section{Oil Yield Per Voyage}

The variability in oil collection in different years could be due to differences in sealing effort. It was difficult to assess sealing effort directly, therefore the amount of oil removed per voyage was used as an index of return per unit of sealing effort (fig. 2). The number of tuns removed per ship fluctuated between 1810 and 1819 , but in 1820 it increased dramatically. From 1821 the amount of oil returned per sealing voyage decreased steadily from 117 tuns to 26 tuns in 1828 . Such a drop in return per unit effort for the sealers during this time would strongly suggest that the available resources were rapidly being depleted. Cumpston (1968) gives several anecdotal examples of how the sealers were finding it difficult to find seals in these later years. 


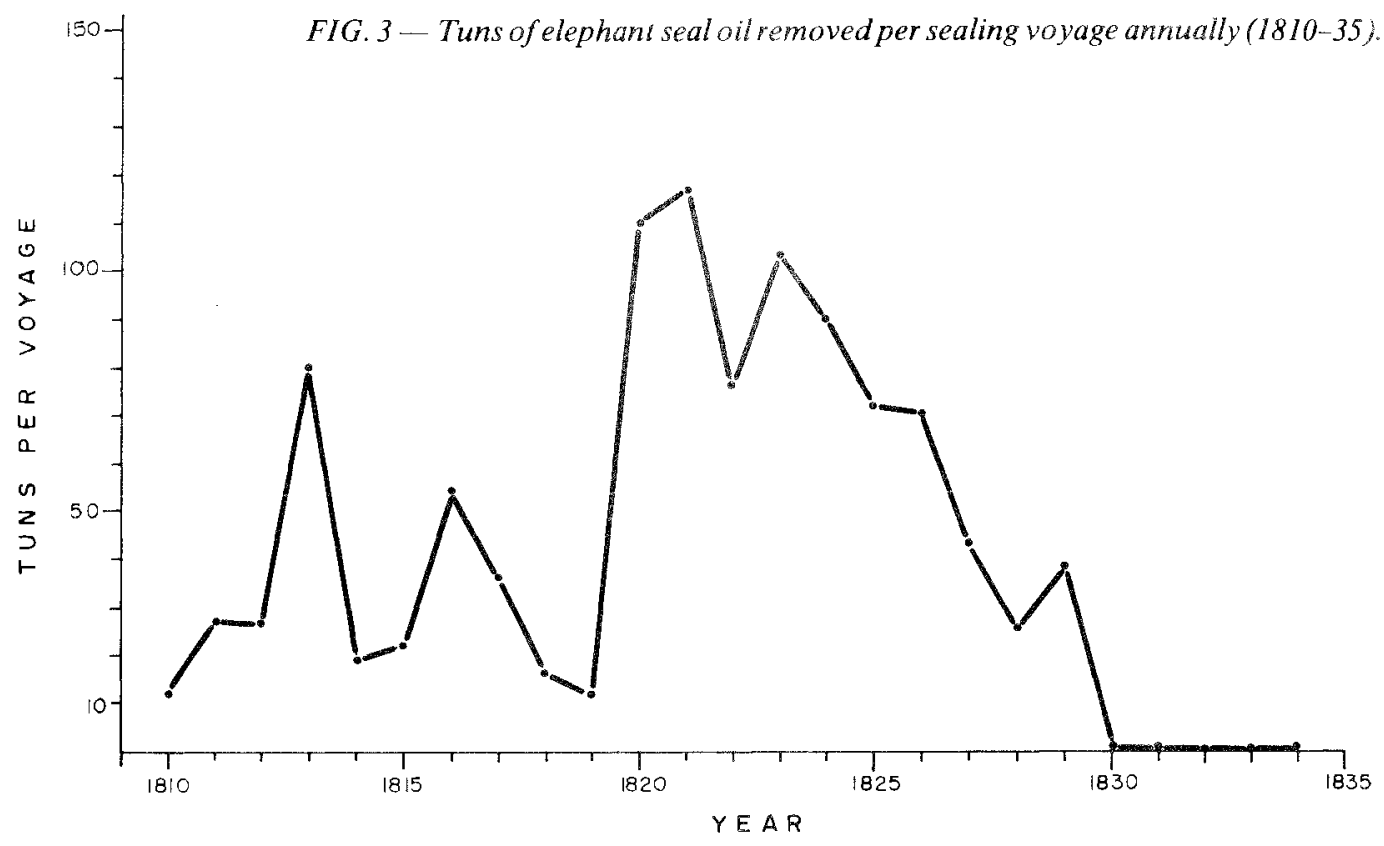

\section{Initial Population Size and the Impact of Sealing Between 1810 and 1829}

The model identified an initial population size of 66100 as the smallest population that could have supported the estimated sealing level. This population size would have required that all of the males available were taken each year from 1821 on (fig. 3). In those years considerable numbers of females would also have had to be taken to produce the estimated oil yields.

An initial population of 80000 would produce an abundant number of males (3000-4500), far in excess of what was taken for the first 13 years, but in the decade of heavy sealing pressure, the number of males available was greater than or equal to the number taken in five years. Females would need to have been taken in the remaining five years of this period to account for the observed amount of oil removed

Initial populations of 100000 or 120000 would have been little affected by the first 12 years of relative low sealing pressure, and during the intense hunting the number of males taken exceeded the number available in only three years, with females needing to be taken in those years. If the original population was 150000 , the number of males available would have exceeded the number taken in all but one year.

The steady decline in the tuns of oil removed from the island per voyage in the nine years from 1821-1830 (fig. 2) suggests that it was becoming progressively more difficult to find seals. Given this, the relative abundances of males produced by the theoretical population size of 150000 seem to rule out populations of this or greater sizes originally existing on the island. A pre-sealing population of between 80000 and 120000 would seem to best fit the observed sealing pressure and the consequent decline in sealing returns.

A population from the middle of this range ( 100000$)$ would have declined to a low of 26183 in 1827 ; an overall decline of $67 \%$, with a total of 21979 males and 15648 females taken (table 2).

This interpretation has assumed that all of the seals on the island were exploited by the sealers, but there is some evidence to suggest that this might not be the case. The sealers seem to have concentrated their activities in the areas of highest population numbers and there are no written records of any activity on the west coast between Bauer Bay and Caroline Cove (Cumpston 1968). This stretch of coast is particularly exposed and rugged, offering no anchorage to ships, so any oil collected here would have been very difficult to remove. Also, there were probably relatively few seals there. In 1985, only $15.8 \%$ of the island's seals were located along this piece of coast (Hindell \& Burton 1987). Consequently, the estimates of initial population size are probably underestimates. When 


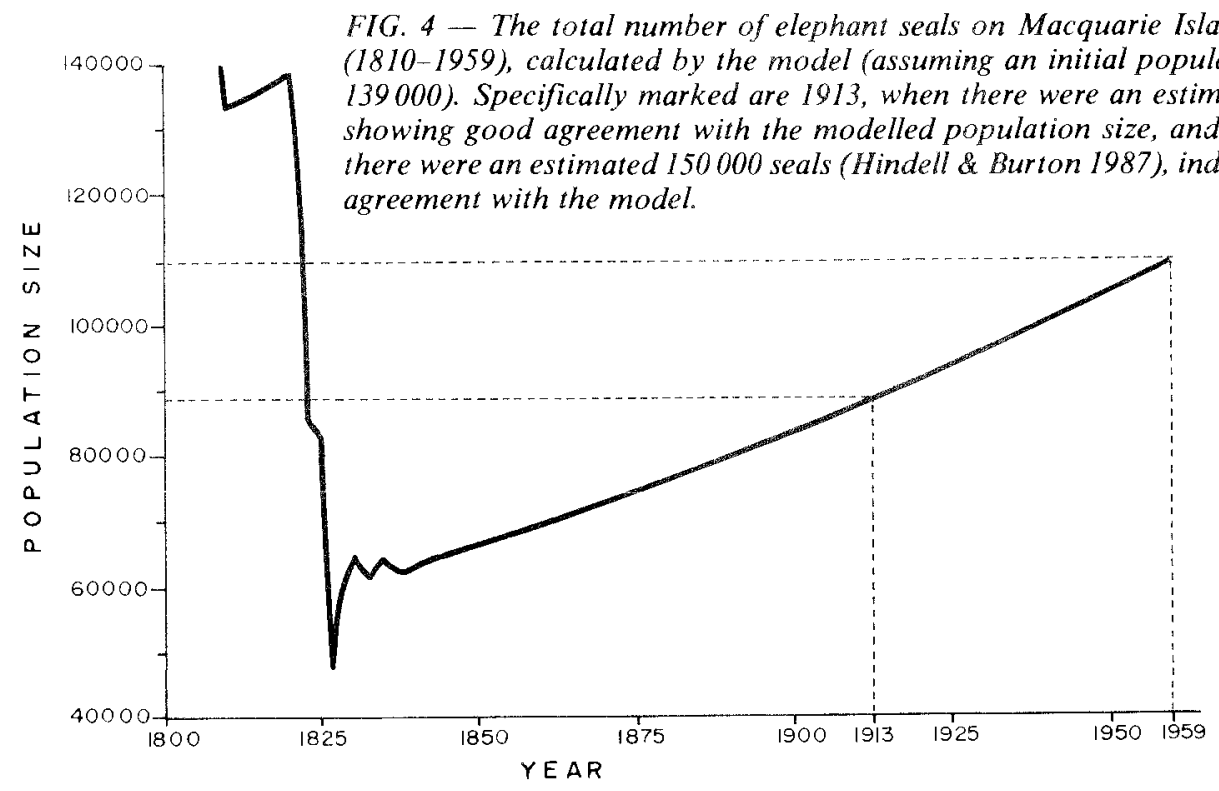

they are corrected by allowing for $15.8 \%$ more seals that were unexploited, the new estimate becomes between 93000 and 143000 .

Estimate of Population Size in 1913 and the Impact of Sealing in the 1900's

In 1913; a team of scientists from the Australasian Antarctic Expedition (AAE) spent a year on Macquarie Island (Cumpston 1968). During this time they estimated that approximately 25000 seals were ashore in the 1913 breeding season. Assuming this was a count of all the seals, male and female, with a sex ratio of $1: 11$ (Hindell \& Burton 1987), there must have been approximately 23000 females ashore. This figure can be used, in turn, to estimate total population size by multiplying by 3.5 (McCann 1985, Hindell \& Burton 1987) and yields a total population size of around 88000 . A population of this size would produce an annual surplus of approximately 660 males, which is precisely the average number of seals removed each year (table 1 ).

The model predicted that a pre-sealing population of 117000 seals, or 139500 correcting for the unexploited west coast animals, would have recovered from a low of 54000 , after the heavy exploitation of the first sealing phase, to a population of around 63000 by the time sealing resumed in 1875 , and would have reached the observed level of 88000 by 1913 (fig. 4). When the model was allowed to continue through until the end of 1959 ,
TABLE 2

Total population size and estimated numbers taken by sealers, 1810-29, for the initial population size of 100000

\begin{tabular}{lrrr} 
Date & $\begin{array}{c}\text { Population } \\
\text { Size }\end{array}$ & $\begin{array}{c}\text { Number of } \\
\text { Males } \\
\text { Taken }\end{array}$ & $\begin{array}{c}\text { Number of } \\
\text { Females } \\
\text { Taken }\end{array}$ \\
\hline 1809 & 100000 & 0 & 0 \\
1810 & 95246 & 375 & 0 \\
1811 & 95779 & 1435 & 0 \\
1812 & 96149 & 710 & 0 \\
1813 & 96412 & 420 & 0 \\
1814 & 96607 & 400 & 0 \\
1815 & 97007 & 455 & 0 \\
1816 & 97477 & 280 & 0 \\
1817 & 97965 & 550 & 0 \\
1818 & 98318 & 255 & 0 \\
1819 & 98697 & 325 & 0 \\
1820 & 99115 & 2310 & 0 \\
1821 & 82123 & 3065 & 0 \\
1822 & 71964 & 1610 & 0 \\
1823 & 51334 & 2189 & 11418 \\
1824 & 50301 & 945 & 0 \\
1825 & 47392 & 1530 & 0 \\
1826 & 34319 & 2431 & 2202 \\
1827 & 26183 & 1824 & 2028 \\
1828 & 31707 & 255 & 0 \\
1829 & 33307 & 615 & 0 \\
Total & & 21979 & 15648 \\
\hline & & &
\end{tabular}


when there are good island-wide counts, the theoretical population only reached 92000 , compared to the observed 156000 (Hindell $\&$ Eurton 1987).

\section{DISCUSSION}

It should be stressed, at the outset, that the conclusions discussed here are based on estimates, and in some cases quite broad esimates. The records derived from the sealers' activivies, and hence our calculated oil yields, were often sketchy; much of the information used to formulate the population model was based on assumptions that are difficult to test. Despite this, we consider that the results still form a useful framework for some speculations on the past impact of sealing on Macquarie Island's elephant seal population.

\section{The History of the Elephant Seal Industry on Macquarie Island}

The shipping records appear to be essentially complete, and clearly demonstrate that the sealing effort at Macquarie island was far from constant over the 106 years that the elephant seal population was exploited. The first 20 years saw the most intensive sealing activity. Almost half of all the sealing voyages occurred between 1811 and 1829 . It is apparent from the estimated annual oil yield during this time that for the first ten years (1810-19) the sealers paid relatively little attention to the elephant seals. Initially the sealers were attracted to Macquarie Island, not for the elephant seal oil, but for the more profitable fur seal skins (Cumpston 1968). Further, the existence of a British Government duty on colonial oil (Cumpston 1968) probably discouraged exploitation of elephant seals. It is likely that the lifting of this duty in 1820 was linked with the beginning of the most intensive period of exploitation.

Approximately 4428 tuns of the total 8280 tuns of oil collected were removed in the next ten years. Thus, this relatively brief period would have seen the major impact on the population. This is supported by the observation that there was a steady decline in the return per unit sealing effort during this ten-year period.

The population would have increased during the 45 years following 1830 , when there was little or no sealing activity. When sealing did resume, in 1875 , it was at a fairly low level and seems to have been opportunistic, with an average of only 46 tuns of oil collected annually, Under the Hatch adminis tration (1890-1919) there were usually three visits to the island annually, removing approximately 660 seals. Towards the end of this period, in 1913 , the population was about 88000 and producing an annual surpius of about 660 , so the level of sealing at this time was unlikely to lead to long-term population decine.

If most of the seals killed from 1870 onwards were males, approximately 14100 seals (2820 tuns at 0.2 tuns per male) would have been killed in this period. Combined with the estimated 38000 seals, both males and females, killed between 1810 and 1829 (table 2) this gives a total of approximately 52000 seals killed during the 109 years of exploitation on Macquarie Island. This is far fewer than the 300000 seals estimated by Busch (1985), and suggests that his estimate of the total world-wide harvest of 1000000 southern elephant seals may be too high.

\section{Estimates of Pre-Sealing Population Size}

The model of the exploited elephant seal population defined the initial size of the population at Macquarie Island as approximately 93000 143000 in order to sustain the level of sealing during the first two decades of exploitation. This presumes that all of the assumptions of the model hold, and that the observed decline in the amount of oil removed per ship between 1820 and 1830 really does reflect a decline in the return for similar sealing effort.

The model required an initial population size of 139500 seals to produce a population of 88000 in 1913, and predicted a fairly slow and constant rate of increase between 1830 and 1875 (fig. 4). However, northern elephant seals (Mirounga angustirostris) exhibited exponential population growth when sealing was stopped (Bartholomew \& Hubbs 1960) and similar exponential growth has been reported for fur seal populations when sealing ceased (Payne 1978). Also, the Macquarie Island elephant seal population displayed much more rapid growth between 1919 and 1959 than was predicted by the model, suggesting that our model is inadequate in describing the increase phase of an elephant seal population. A possible problem with the model is use of age-specific mortalities from the stable South Georgia population. These data would have been adequate for the model during the times that the population was under exploitation, although the annual recruitment may have been overestimated. The population increase at Macquarie Island may have been due to changes in 
several population parameters, such as an increase in fecundity, reduced mortality in some or all age classes, or a. change in the age at first breeding. Many of these processes are density dependent, and the failure of the model ro incorporate them will result in underestimation of the rate of recovery and so overestimation of the invial population size. Unfortunately, there is no life history data available for southern elephant seals during a recovery phase, so it is difficult to know how the models should be adjusted to enable more accurate predictions. Thus, an initial population size of 139500 could be an overestimate, and the initial population size of the Macquarie Island seals may be closer to the lower limits of the range, that is around $93000-110000$.

This suggests that, by 1913 , the population had recovered to near the pre-sealing levels. Perhaps the level of sealing after 1890 was sufficient to maintain the population at just below the presealing levels, allowing the seals prey (thought to be fish and squid, Laws 1960) to increase to higher than normal levels. With the end of sealing, the population may have expanded beyond the presealing levels to the high levels observed in the 1950's, due to an abundance of food. The recently described decline in elephant seal numbers at Macquarie Island (Hindell \& Burton 1987) may be a result of the population returning to equilibrium. However, when the exploitation of the South Georgia elephant seal population ceased in 1964 , after over a century of sealing (Laws 1981), there was no subsequent increase in population size over the next 25 years (McCann, pers. comm.). In the later years, at least, the South Georgia elephant seal industry was carefully managed to ensure the number of males removed did not exceed the annual surplus (Laws 1960), as may have been the case at Macquarie Island between 1890 and 1916 (although it is unlikely that this was a deliberate policy). The reasons for the different responses of the two populations are unclear but may reflect differences between them in fundamental ecological parameters. More information on these parameters, such as specific life history data for the Macquarie Island population, will be necessary to resolve this question.

\section{ACKNOWLEDGEMENTS}

We wish to thank Rhys Richards, not only for suggesting several invaluable sources of shipping records, but also for his encouragement and advice in the details of calculating "elephant seal equivalents" from the shipping records of oil tunnage. Geoff Kirkwood of CSIRO also provided much advice and encouragement in the design of the elephant seal population model.

\section{REFERENCES}

ALLEN, K.R. K KRKWOOD, G.P., 1978: Simulation of Southern Hemisphere sei whale stocks. Rep. Int. Whal. Comm., 28: 151-157.

BARTHOLOMEW, G.A. \& HUBBS, C.L., 1960: Population growth and seasonal movements of the northern elephant seal, Mirounga angustirostris. Mammalia, 24: 313-324.

BEDDINGTON, J.R. \& KIRKWOOD, G.P., I980: On the mathematical structure of possible sperm whale models. Rep. Int. Whal. Comm., Special Issue, 2: 57-58.

BRYDEN, M.M., 1968: Growth and function of the subcutaneous fat of the elephant seal. Nature, 220: $597-599$

BRYDEN M.M. \& STOKES, G.B., 1969: Metabolism of fatty acids in the southern elephant seal Mirounga leonina L. Can. J. Biochem., 47: $757-760$.

BUSCH, B.C., I985: THE WAR AGAINST THE $S E A L S$. Gill-Queens University Press, Canada.

CARRICK, R.\& INGHAM, S.E., 1962a: Studies of the Southern elephant seal, Mirounga leonina (L.) I. Introduction to the series. CSIRO Wildl. Res. 7: $89-101$

CARRICK, R. \& INGHAM, S.E. 1962b: Studies of the Southern elephant seal, Mirounga leonina (L.). V. Population dynamics and utilization. CSIRO Wildl. Res., 7(2): 198-206.

CARRICK, R., CSORDAS S.E. \& INGHAM, S.E., 1962: Studies of the southern elephant seal Mirounga leonina (L.). IV. Breeding and development. CSIRO Wildl. Res., 7: 161-197.

CUMPSTON, J.S., 1963: SHIPPING ARRIVALS AND DEPARTURES. VOL, I SYDNEY 1788-1825. Roebuck, Canberra.

CUMPSTON, J.S., 1968: Macquarie Island. ANARE Sci. Rep., Ser.A(1), 93: 1-380.

GALES, N.J. \& BURTON, H.R., I987: Ultrasonic measurement of blubber thickness of the southern elephant seal Mirounga leonina(L.). Aust. J. Zool., 35.

GRIFFITHS, D.J., I984: The annual cycle of the test is of the elephant seal (Mirounga leonina) at Macquarie Island. J. Zool. (Lond.), 203: 193-204.

HAMILTON, J.E., 1949: Weight etc., of elephant seal. Nature, 163: 536 . 
HAMILTON, R., 1839: THE NATURAL HISTORY OF THE AMPHIBIOUS CARNIVORA, INCLUDING THE WALRUS AND SEALS, ALSO OF THE HERBIVOROUS CETACEA, ETC. W.H. Lizars, Edinburgh.

HINDELL, M.A. \& BURTON, H.R. (1987): The past and present status of the southern elephant seal Mirounga leonina (Linn.) at Macquarie Island. J. Zool. (Lond.), 213

JONES, E., 1981: Age in relation to breeding status of the male southern elephant seal, Mirounga leonina (L.), at Macquarie Island. Aust. Wildl. Res., 8: 327-334.

KEMP, P., 1976: THE OXFORD COMPANION TO SHIPS AT SEA. Oxford University Press, London.

KERR, I.S., 1976: CAMPBELL ISLAND. A HISTORY. A.H. and A.W. Reed Ltd, Wellington.

LAWS, R.M., 1960: The southern elephant seal (Mirounga leonina Linn.) at South Georgia. Norsk Hvalfangst-Tidende, 10, 11: 466-476, $520-542$.

LAWS, R.M., 1981: Biology of Antarctic seals. Sci. Prog. Ox., 67: 377-397.

LING, J.K. \& BRYDEN, M.M., 1981: Southern elephant Seal Mirounga leonina Linnaeus, 1758. In Ridgeway, S. H. \& Harrison, R.J. (Eds): $H A N D$ BOOK OF MARINE MAMMALS, Vol.2. Academic Press, London: 297-327.

McCANN, T.S., 1980: Population structure and social organization of southern elephant seals, Mirounga leonina (L.). Biol. J. Linn. Soc., 14 133-150.
MCCANN, T.S., 1985: Size, status and demography of southern elephant seal Mirounga leonina populations. In Ling, L.K. \& Bryden, M.M. (Eds) SEA MAMMALS OF SOUTH LATITUDES Proceedings of a symposium of the 52 nd ANZAAS Congress. South Aust ralian Museum: $1-17$

NICHOLSEN, 1.H., 1963: SHIPPING ARRIVALS AND DEPARTURES. SYDNEY. Vol.IL 1826-1840. Roebuck, Canberra

NICHOLSEN, 1.H., 1983: SHIPPING ARRIVALS AND DEPARTURES. TASMANIA. Vol.I 1803-1833. Roebuck, Canberra.

NICHOLSEN, 1.H., 1985: SHIPPING ARRIVALS AND DEPARTURES. TASMANIA. VOLIII, 1834-1842. Roebuck, Canberra.

PAYNE, M.R. 1978: Population size and age determination in the Antarctic Fur seal Arctocephalus gazella. Mamm. Rev., 8: 67-73.

SCAMMON, C.M., 1874: THE MARINE MAMMALS OF THE NORTH-WESTERN COAST OF NORTH AMERICA. Described and lllustrated. Together With an Account of the American Whale-fishery. John H. Carmany and Co., San Francisco.

SHAUGHNESSY, P.D.\& BEST, P.B., 1982: A discrete population model for the South African fur seal Arctocephalus pusillus pusillus. In MAMMALS OF THE SEAS, FAO Fisheries Series.

WINTER, G. \& NUNN, W.J., 1950: The component fatty acids of elephant seal oil: the distribution in the body. J. Sci. Food Agr., 10: 311-314.

(accepted 3 December 1987) 


\section{APPENDIX}

A complete shipping list of all vessels to call at Macquarie Island between 1810 and 1919.

\section{Compiled from Cumpston (1963, 1968), Nicholsen (1963, 1983, 1985).}

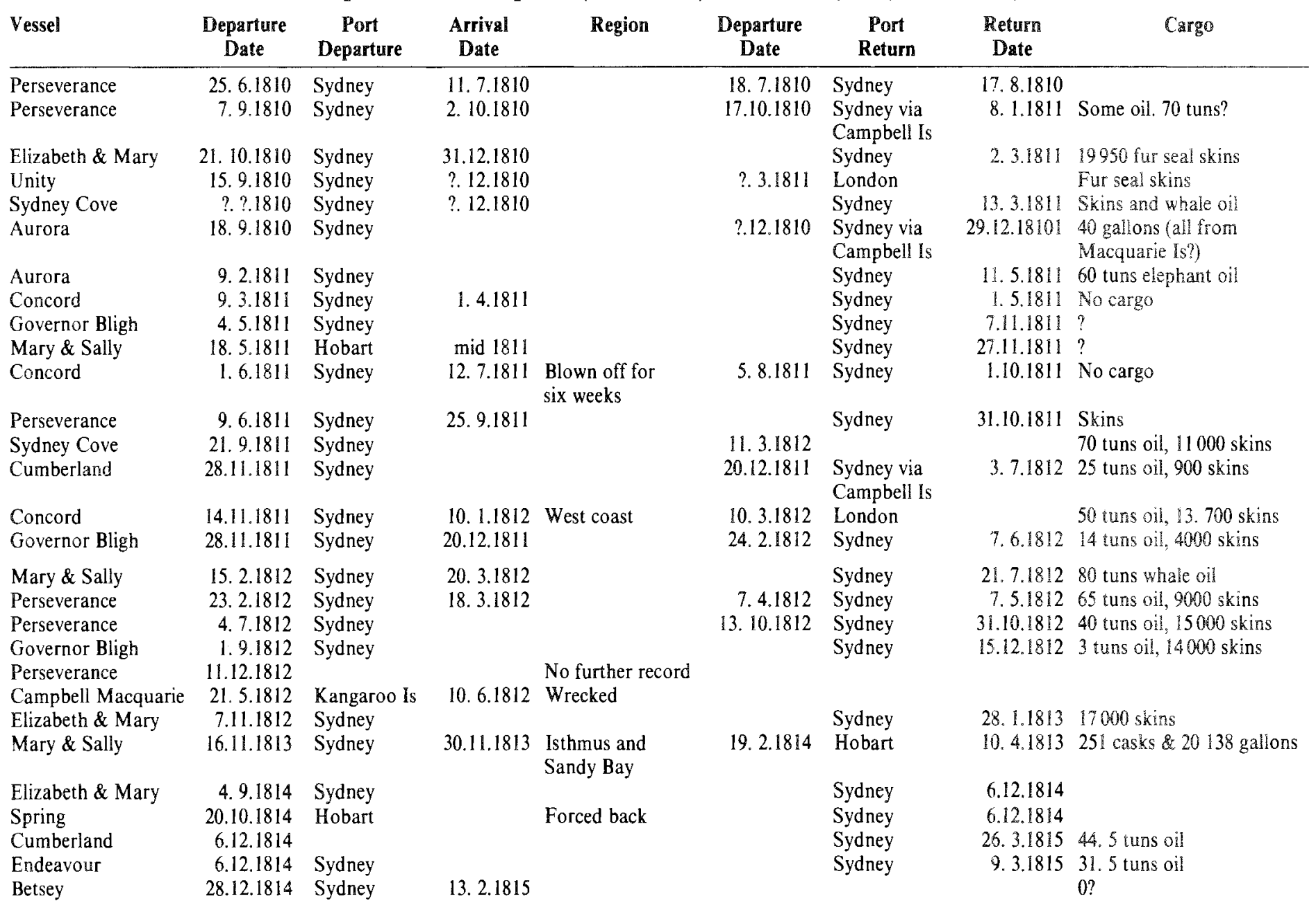




\begin{tabular}{|c|c|c|c|c|c|c|c|c|}
\hline Vessel & $\begin{array}{c}\text { Departure } \\
\text { Date }\end{array}$ & $\begin{array}{c}\text { Port } \\
\text { Departure }\end{array}$ & $\begin{array}{c}\text { Arrival } \\
\text { Date }\end{array}$ & Region & $\begin{array}{c}\text { Departure } \\
\text { Date }\end{array}$ & $\begin{array}{c}\text { Port } \\
\text { Return }\end{array}$ & $\begin{array}{c}\text { Return } \\
\text { Date }\end{array}$ & Cargo \\
\hline $\begin{array}{l}\text { Elizabeth \& Mary } \\
\text { Betsey } \\
\text { Cumberland } \\
\text { Elizabeth \& Mary }\end{array}$ & $\begin{array}{r}14.1 .1815 \\
? .8 .1815 \\
24.6 .1815 \\
8.8 .1815\end{array}$ & $\begin{array}{l}\text { Sydney } \\
\text { Sydney } \\
\text { Sydney } \\
\text { Sydney }\end{array}$ & & $\begin{array}{l}\text { Via Campbell Is } \\
\text { Did not arrive }\end{array}$ & & Sydney & 11.11 .1815 & 2690 skins \\
\hline $\begin{array}{l}\text { Elizabeth \& Mary } \\
\text { Elizabeth \& Mary }\end{array}$ & $\begin{array}{l}26.3 .1816 \\
27.9 .1816\end{array}$ & $\begin{array}{l}\text { Sydney } \\
\text { Sydney }\end{array}$ & & & & $\begin{array}{l}\text { Sydney } \\
\text { Sydney }\end{array}$ & $\begin{array}{l}28.5 .1816 \\
21.1 .1817\end{array}$ & $\begin{array}{l}30 \text { tuns oil, } 1200 \text { skins } \\
23.5 \text { tuns oil }\end{array}$ \\
\hline $\begin{array}{l}\text { Elizabeth \& Mary } \\
\text { Elizabeth \& Mary } \\
\text { Campbell Macquarie } \\
\text { Elizabeth \& Mary }\end{array}$ & $\begin{array}{r}13.7 .1817 \\
16.10 .1817 \\
9.11 .1817 \\
17.12 .1817\end{array}$ & $\begin{array}{l}\text { Sydney } \\
\text { Sydney } \\
\text { Sydney }\end{array}$ & & & & $\begin{array}{l}\text { Sydney } \\
\text { Sydney } \\
\text { Sydney } \\
\text { Sydney }\end{array}$ & $\begin{array}{r}1.9 .1817 \\
26.11 .1817 \\
9.2 .1818 \\
10.2 .1818\end{array}$ & $\begin{array}{l}20 \text { tuns oil } \\
\text { Cargo of oil } \\
52 \text { tuns oil } \\
14 \text { tuns oil }\end{array}$ \\
\hline $\begin{array}{l}\text { Elizabeth \& Mary } \\
\text { Elizabeth \& Mary } \\
\text { Governor Bligh } \\
\text { Elizabeth \& Mary } \\
\text { Elizabeth \& Mary } \\
\text { Campbell Macquarie } \\
\text { Elizabeth \& Mary }\end{array}$ & $\begin{array}{r}7.3 .1818 \\
6.8 .1818 \\
22.8 .1818 \\
25.1 .1819 \\
23.6 .1819 \\
12.9 .1819 \\
8.12 .1819\end{array}$ & $\begin{array}{l}\text { Sydney } \\
\text { Sydney } \\
\text { Sydney } \\
\text { Sydney } \\
\text { Sydney } \\
\text { Sydney }\end{array}$ & & $\begin{array}{l}\text { Via Campbell Is } \\
\text { Via New Zealand } \\
\text { Via New Zealand }\end{array}$ & & $\begin{array}{l}\text { Sydney } \\
\text { Sydney } \\
\text { Sydney } \\
\text { Sydney } \\
\text { Sydney } \\
\text { Sydney } \\
\text { Sydney }\end{array}$ & $\begin{array}{r}13.7 .1818 \\
21.12 .1818 \\
30.3 .1819 \\
2.3 .1819 \\
1.11 .1819 \\
3.12 .1819 \\
27.1 .1820\end{array}$ & $\begin{array}{l}8.8 \text { tuns oil } \\
26.5 \text { tuns oil } \\
10516 \text { skins } \\
17 \text { tuns oil, } 1243 \text { skins } \\
33 \text { tuns oil, } 3190 \text { skins } \\
12 \text { tuns oil } \\
4397 \text { skins }\end{array}$ \\
\hline $\begin{array}{l}\text { Elizabeth \& Mary } \\
\text { Regalia } \\
\text { Robert Quayle } \\
\text { Regalia } \\
\text { Bellingshausen }\end{array}$ & $\begin{array}{r}12.3 .1820 \\
26.8 .1820 \\
8.9 .1820 \\
1.12 .1820\end{array}$ & $\begin{array}{l}\text { Sydney } \\
\text { Hobart } \\
\text { Hobart } \\
\text { Sydney }\end{array}$ & 28.11 .1820 & $\begin{array}{l}\text { South End } \\
\text { South End } \\
\text { South End }\end{array}$ & 13.11 .1820 & $\begin{array}{l}\text { Sydney } \\
\text { Sydney } \\
\text { London } \\
\text { Hobart }\end{array}$ & $\begin{array}{r}11.5 .1820 \\
21.10 .1820 \\
1.3 .1821\end{array}$ & $\begin{array}{l}30 \text { tuns oil } \\
0 ? \\
150 \text { tuns } \\
260 \text { tuns }\end{array}$ \\
\hline $\begin{array}{l}\text { Midas } \\
\text { Emerald } \\
\text { Elizabeth \& Mary }\end{array}$ & $\begin{array}{r}10.5 .1821 \\
12.5 .1821 \\
6.8 .1821\end{array}$ & $\begin{array}{l}\text { Hobart } \\
\text { Hobart } \\
\text { Sydney }\end{array}$ & & $\begin{array}{l}\text { North End } \\
\text { South End } \\
\text { North End } \\
\text { \& Campbell Is }\end{array}$ & & $\begin{array}{l}\text { Hobart } \\
\text { Hobart } \\
\text { Sydney }\end{array}$ & $\begin{array}{r}1.8 .1821 \\
11.9 .1821 \\
? .1 .1822\end{array}$ & $\begin{array}{l}0 \\
\text { Live elephant seal }\end{array}$ \\
\hline Surrey & 5. 9.1821 & Sydney & 24.9 .1821 & $\begin{array}{l}\text { North End and } \\
\text { Lusitania Bay }\end{array}$ & 21.11 .1821 & Sydney & 6.12 .1821 & 180 tuns oil \\
\hline $\begin{array}{l}\text { Midas } \\
\text { Emerald }\end{array}$ & $\begin{array}{r}27.9 .1821 \\
7.11 .1821\end{array}$ & Hobart & 16.11 .1821 & Lusitania Bay & & $\begin{array}{l}\text { Sydney } \\
\text { Hobart }\end{array}$ & $\begin{array}{l}23.1 .1822 \\
15.6 .1822\end{array}$ & $\begin{array}{l}300 \text { tuns oil } \\
104 \text { tuns oil }\end{array}$ \\
\hline $\begin{array}{l}\text { Lusitania } \\
\text { Elizabeth \& Mary } \\
\text { Emerald } \\
\text { Mariner }\end{array}$ & $\begin{array}{r}14.2 .1822 \\
5.5 .1822 \\
13.9 .1822 \\
26.9 .1822\end{array}$ & $\begin{array}{l}\text { Hobart } \\
\text { Sydney } \\
\text { Hobart } \\
\text { Sydney }\end{array}$ & ?. 3.1822 & $\begin{array}{l}\text { North End } \\
\text { South End }\end{array}$ & & $\begin{array}{l}\text { London } \\
\text { Sydney } \\
\text { Hobart } \\
\text { Sydney }\end{array}$ & $\begin{array}{r}4.9 .1822 \\
31.10 .1822 \\
10.12 .1822\end{array}$ & $\begin{array}{l}30 \text { tuns oil } \\
50 \text { tuns oil } \\
150 \text { tuns oil } \\
262 \text { tuns (or. } 77 \text { tuns*) }\end{array}$ \\
\hline
\end{tabular}




$\begin{array}{lrl}\text { Elizabeth \& Mary } & 21.1 .1823 & \text { Sydney } \\ \text { Lynx } & 28.1 .1823 & \text { Sydney } \\ \text { Regalia } & 13.3 .1823 & \text { Sydney } \\ \text { Wellington } & 1.4 .1823 & \text { Sydney } \\ & & \\ \text { Caroline } & 17.4 .1823 & \text { Hobart } \\ \text { Elizabeth \& Mary } & 26.4 .1823 & \text { Sydney } \\ \text { Perseverance } & 16.9 .1823 & \text { Sydney } \\ \text { Caroline } & 25.9 .1823 & \text { Hobart } \\ \text { Wellington } & 10.10 .1823 & \text { Sydney } \\ \text { Elizabeth \& Mary } & 29.10 .1823 & \text { Sydney } \\ \text { Midas } & 22.12 .1823 & \text { Sydney } \\ \text { Caroline } & 4.4 .1824 & \text { Sydney } \\ \text { Perseverance } & 21.9 .1824 & \text { Sydney } \\ \text { Caroline } & 17.11 .1824 & \text { Sydney } \\ & & \\ \text { Cypress } & 17.8 .1825 & \text { Hobart } \\ \text { Wellington } & & \\ \text { Wellington } & 2610.1825 & \text { Sydney } \\ \text { Perseverance } & 24.10 .1825 & \text { Sydney } \\ \text { Elizabeth \& Mary } & 10.1 .1826 & \text { Sydney } \\ \text { Perseverance } & 6.2 .1826 & \text { Sydney } \\ \text { Brutus } & 9.3 .1826 & \text { Sydney } \\ \text { Lord Rodney } & 4.5 .1826 & \text { Sydney } \\ \text { Elizabeth \& Mary } & 14.7 .1826 & \text { Sydney } \\ \text { Sydney Packet } & 18.8 .1826 & \text { Sydney } \\ \text { Perseverance } & 11.9 .1826 & \text { Sydney } \\ \text { Lord Rodney } & 15.11 .1826 & \text { Sydney } \\ \text { Sydney Packet } & 1.1 .1827 & \text { Hobart } \\ \text { Perseverance } & 2.1 .1827 & \text { Sydney } \\ \text { Lord Rodney } & 23.1 .1827 & \\ \text { Elizabeth \& Mary } & 13.4 .1827 & \\ \text { Elizabeth \& Mary } & 2.8 .1827 & \text { Sydney } \\ \text { Perseverance } & 20.8 .1827 & \text { Sydney } \\ \text { Governor Arthur } & 11.9 .1827 & \text { Sydney } \\ \text { Perseverance } & 8.11 .1827 & \text { Sydney } \\ \text { Rolls } & 11.11 .1827 & \text { Sydney } \\ \text { Governor Arthur } & 6.12 .1827 & \text { Sydney } \\ & & \\ & & \\ & & \end{array}$

North End

North End

South End

Via Campbell Is

North End

South End

Via Campbell Is

South End

North End

15. 2.1825 Wrecked

17. 2.1825

17. 9.1825 South End

North End

North End

Via New Zealand

North End

Via New Zealand

Caroline Cove

22.12.1826 Caroline Cove

West Coast

Via New Zealand

North End

South End
Sydney

Sydney

Sydney

Sydney

Hobart

Sydney

Sydney

Sydney

Sydney

Sydney

Sydney

Sydney

Sydney

Hobart

Sydney

Sydney

Sydney

Sydney

12. 4.1826

Sydney

Sydney

Sydney

Sydney

Sydney

Hobart

Sydney

1. 3.1827 Sydney

Sydney

Sydney

Sydney
1. 6.1827 Sydney

25.3 .182351 tuns oil

18. 7.1823150 tuns (15 tuns*)

29. 5.1823282 tuns oil

22. 9.1823 "Cargo of oil",

$$
\text { 4000-5000 skins }
$$

11. 7.1823 "Cargo of oil"

23. 9.18236 tuns oil, 814 skins

30.10 .182360 tuns oil

1.1824180 tuns oil

3. 4.1824 Skins only

17. 3.182410 tuns oil, 3500 skins

7. 2.1824330 tuns oil

22. 4.182490 tuns oil

23. 2.18250 ?

160 tuns oil

1.10 .182566 tuns oil

18. 9.1825100 tuns oil, 1800 skins

$22.12 .1825 \quad 65$ tuns oil

27.12.1825 60 tuns oil

3. 6.18267 tuns oil, 4000 skins

2. 4.1826 60 tuns oil

$$
200 \text { tuns oil }
$$

26. $6.1826 \quad 120$ tuns oil

12. 3.182710 tuns oil, 300 skins

23.10.1826 "Cargo of oil"

3.12 .182676 tuns oil

21.12.1826 "Cargo of oil"

25. 2.182756 tuns oil

14. $3.1827 \quad 70$ tuns oil

21. 3.1827100 tuns oil

20.6.1827 "Skins and oil"

10.12.1827 11 tuns oil (18 tuns*)

1.11.1827 15 tuns oil

7. 2.182870 tuns oil

17. 1.1828 Sydney

7. 2.18288 tuns oil 


\begin{tabular}{|c|c|c|c|c|c|c|c|c|}
\hline Vessel & $\begin{array}{l}\text { Departure } \\
\text { Date }\end{array}$ & $\begin{array}{c}\text { Port } \\
\text { Departure }\end{array}$ & $\begin{array}{c}\text { Arrival } \\
\text { Date }\end{array}$ & Region & $\begin{array}{l}\text { Departure } \\
\text { Date }\end{array}$ & $\begin{array}{c}\text { Port } \\
\text { Return }\end{array}$ & $\begin{array}{c}\text { Return } \\
\text { Date }\end{array}$ & Cargo \\
\hline $\begin{array}{l}\text { Elizabeth \& Mary } \\
\text { Elizabeth \& Mary } \\
\text { Blues }\end{array}$ & $\begin{array}{r}9.6 .1828 \\
6.12 .1828 \\
19.4 .1828\end{array}$ & $\begin{array}{l}\text { Sydney } \\
\text { Sydney } \\
\text { Sydney }\end{array}$ & & $\begin{array}{l}\text { Via New Zealand } \\
\text { Via New Zealand } \\
\text { South End }\end{array}$ & & $\begin{array}{l}\text { Sydney } \\
\text { Sydney } \\
\text { Rio de Janiero }\end{array}$ & $\begin{array}{l}7.9 .1828 \\
7.4 .1829\end{array}$ & $\begin{array}{l}\text { "Oil and skins" } \\
\text { "Oil and skins" } \\
?\end{array}$ \\
\hline $\begin{array}{l}\text { Elizabeth \& Mary } \\
\text { Faith }\end{array}$ & $\begin{array}{r}20.5 .1829 \\
22.12 .1829\end{array}$ & $\begin{array}{l}\text { Sydney } \\
\text { Sydney }\end{array}$ & & $\begin{array}{l}\text { Via New Zealand } \\
\text { South End }\end{array}$ & & $\begin{array}{l}\text { Sydney } \\
\text { Sydney }\end{array}$ & $\begin{array}{l}23.9 .1829 \\
18.4 .1830\end{array}$ & $\begin{array}{l}18 \text { tuns oil, } 330 \text { skins } \\
60 \text { tuns oil (left } 120 \text { tuns) }\end{array}$ \\
\hline $\begin{array}{l}\text { Eleanor } \\
\text { Bree (Bee?) }\end{array}$ & $\begin{array}{r}19.3 .1834 \\
16.11 .1834\end{array}$ & $\begin{array}{l}\text { Sydney } \\
\text { Hobart }\end{array}$ & & & & $\begin{array}{l}\text { Sydney } \\
\text { Sydney }\end{array}$ & $\begin{array}{r}7.6 .1834 \\
20.12 .1834\end{array}$ & $\begin{array}{l}1 \text { cask } \\
0 \text { tuns }\end{array}$ \\
\hline Вгеe (Веe?) & & Sydney & & & & Sydney & 19. 5.1835 & 0 tuns \\
\hline Enderby expedition & & & ?. ?.1837 & & & & & "Large number of skins" \\
\hline Lord Nelson & & & ?. ?.1838 & Wrecked & & & & \\
\hline $\begin{array}{l}\text { Peacock } \\
\text { Flying Fish }\end{array}$ & & $\begin{array}{l}\text { USA } \\
\text { USA }\end{array}$ & $\begin{array}{l}10.10 .1840 \\
10.10 .1840\end{array}$ & $\begin{array}{l}\text { South End } \\
\text { South End }\end{array}$ & & & & $\begin{array}{l}0 \\
0\end{array}$ \\
\hline $\begin{array}{l}\text { Lord Duncan } \\
\text { Countess of Minto }\end{array}$ & $\begin{array}{r}? . ? .1851 \\
4.11 .1851\end{array}$ & $\begin{array}{l}\text { Auckland Is } \\
\text { Sydney }\end{array}$ & $\begin{array}{l}3.12 .1851 \\
3.12 .1851\end{array}$ & $\begin{array}{l}\text { Isthmus } \\
\text { Wrecked at the } \\
\text { Nuggets }\end{array}$ & & & & 147 elephant seals killed \\
\hline Brisk & & & 5.4 .1852 & & & & & $?$ \\
\hline Sarah Pile & 11.10 .1873 & Invercargil & 17.11 .1873 & & & & 20.1 .1874 & 0 \\
\hline $\begin{array}{l}\text { Spirit of the Sth } \\
\text { Chance } \\
\text { Chance }\end{array}$ & $\begin{array}{r}\text { ?. } ? .1874 \\
13.9 .1874 \\
? . ? .1874\end{array}$ & $\begin{array}{l}\text { Adelaide } \\
\text { Invercargil }\end{array}$ & 20.6 .1874 & Caroline Cove & & Invercargil & $\begin{array}{r}5.11 .1874 \\
11.1 .1875\end{array}$ & $\begin{array}{l}0 \\
? \\
50 \text { tuns sperm \& } \\
\text { elephant oil }\end{array}$ \\
\hline $\begin{array}{l}\text { Splendid } \\
\text { Splendid } \\
\text { Splendid }\end{array}$ & $\begin{array}{r}12.7 .1876 \\
13.12 .1876\end{array}$ & $\begin{array}{l}\text { Dunedin } \\
\text { Pt William }\end{array}$ & 26.12 .1876 & Isthmus & & $\begin{array}{l}\text { Invercargil } \\
\text { Dunedin }\end{array}$ & $\begin{array}{l}\text { 1. } 4.1875 \\
\text { ?. } 9.1876\end{array}$ & $\begin{array}{l}43 \text { tuns \& } 105 \text { casks oil } \\
? \\
65 \text { tuns oil }\end{array}$ \\
\hline Bencleugh & 10. 7.1877 & Pt Chambers & 27.7 .1877 & $\begin{array}{l}\text { Wrecked on North } \\
\text { Head }\end{array}$ & & & & 15 tuns \\
\hline $\begin{array}{l}\text { Friendship } \\
\text { Friendship }\end{array}$ & $\begin{array}{r}? . ? .1877 \\
9.11 .1877\end{array}$ & Stewart Is & $\begin{array}{r}20.8 .1877 \\
27.11 .1877\end{array}$ & & & & & \\
\hline Jessie Nichol & 29.12 .1877 & Dunedin & & & 29. 1.1878 & Dunedin & 13. 2.1878 & 16 casks oil \\
\hline
\end{tabular}




\begin{tabular}{|c|c|c|c|c|c|c|c|c|}
\hline $\begin{array}{l}\text { Jessie Nichol } \\
\text { Jessie Nichol }\end{array}$ & $\begin{array}{l}25.7 .1878 \\
12.9 .1878\end{array}$ & $\begin{array}{l}\text { Otago } \\
\text { Dunedin }\end{array}$ & 14.8 .1878 & & 1. 9.1878 & $\begin{array}{l}\text { Otago } \\
\text { Dunedin }\end{array}$ & $\begin{array}{r}3.9 .1878 \\
30.10 .1878\end{array}$ & $\begin{array}{l}18 \text { tuns } \\
?\end{array}$ \\
\hline $\begin{array}{l}\text { Jessie Nichol } \\
\text { Jessie Nichol }\end{array}$ & $\begin{array}{r}\text { 7. } 2.1879 \\
17.5 .1879\end{array}$ & & 23.5 .1879 & $\begin{array}{l}\text { Isthmus \& } \\
\text { Sandy Bay }\end{array}$ & & Otago & 22. $6.1879 ?$ & 0 ? \\
\hline Jessie Nichol & 23.11 .1879 & & 1.12 .1879 & $\begin{array}{l}\text { West Coast \& } \\
\text { Isthmus }\end{array}$ & & & 27.12 .1879 & 40 casks \\
\hline Jessie Nichol & 6. 3.1880 & & & & & & 8. 4.1880 & 25 tuns (left 60 tuns) \\
\hline Jessie Nichol & 21.4 .1880 & & & $\begin{array}{l}\text { Lusitania Bay } \\
\text { \& Hurd Pt? }\end{array}$ & & & 1. 6.1880 & ? \\
\hline Jessie Nichol & 3.11 .1880 & & & $\begin{array}{l}\text { Lusitania Bay } \\
\& \text { Isthmus }\end{array}$ & & & 15.12 .1880 & 55 tuns \\
\hline Jessie Nichol & 13. 1.1881 & & & $\begin{array}{l}\text { Lusitania Bay } \\
\text { \& Hurd Pt }\end{array}$ & & & 18. 2.1881 & 48 tuns \\
\hline Jessie Nichol & 29.4 .1881 & & & & & & 8.6 .1881 & 18 tuns \\
\hline $\begin{array}{l}\text { Jessie Nichol } \\
\text { Jessie Nichol }\end{array}$ & $\begin{array}{r}11.1 .1882 \\
6.3 .1882\end{array}$ & & & & & & $\begin{array}{l}\text { 13. } 2.1882 \\
\text { 16. } 5.1882\end{array}$ & $\begin{array}{l}15 \text { casks } \\
\text { "Cargo of oil" }\end{array}$ \\
\hline $\begin{array}{l}\text { Jessie Nichol } \\
\text { Sarah W. Hunt }\end{array}$ & $\begin{array}{r}\text { 3. } 1.1883 \\
? . ? .1883\end{array}$ & & $? .11 .1883$ & & & & 16. 2.1883 & $\begin{array}{l}35 \text { tuns oil } \\
0\end{array}$ \\
\hline Jessie Nichol & 19. 7.1884 & & & Isthmus & & & 21.12 .1884 & 40 tuns \\
\hline $\begin{array}{l}\text { Janet Ramsey } \\
\text { Awarua }\end{array}$ & $\begin{array}{r}18.11 .1887 \\
2.12 .1887\end{array}$ & Invercargil & 7.12 .1887 & & 18. 1.1888 & Invercargil & 27. 2.1888 & $\begin{array}{l}9 \text { tuns } \\
?\end{array}$ \\
\hline $\begin{array}{l}\text { Janet Ramsey } \\
\text { Awarua }\end{array}$ & $\begin{array}{l}\text { 28. } 2.1888 \\
24.3 .1888\end{array}$ & Invercargil & $\begin{array}{r}7.4 .1888 \\
14.4 .1888\end{array}$ & $\begin{array}{l}\text { North and South } \\
\text { Ends }\end{array}$ & & Invercargil & $\begin{array}{l}9.4 .1888 \\
3.7 .1888\end{array}$ & $\begin{array}{l}\text { "Cargo of oil" } \\
35 \text { casks ( } \& 10 \text { tons lost) }\end{array}$ \\
\hline $\begin{array}{l}\text { Janet Ramsey } \\
\text { Awarua }\end{array}$ & $\begin{array}{r}6.10 .1888 \\
29.10 .1888\end{array}$ & $\begin{array}{l}\text { Invercargil } \\
\text { Invercargil }\end{array}$ & 11.11 .1888 & & & Invercargil & 28.12 .1888 & $\begin{array}{l}24 \text { tuns } \\
0\end{array}$ \\
\hline $\begin{array}{l}\text { Janet Ramsey } \\
\text { Awarua }\end{array}$ & 24. 1.1889 & Pt Chambers & 1. 2.1889 & Could not land & & & & \\
\hline $\begin{array}{l}\text { Awarua } \\
\text { Awarua }\end{array}$ & $\begin{array}{r}29.1 .1889 \\
6.6 .1889\end{array}$ & $\begin{array}{l}\text { Invercargil } \\
\text { Pt Chambers }\end{array}$ & 25.6 .1889 & & & $\begin{array}{l}\text { Invercargil } \\
\text { Invercargil }\end{array}$ & $\begin{array}{r}4.3 .1889 \\
17.7 .1889\end{array}$ & 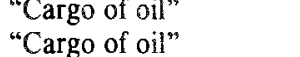 \\
\hline Janet Ramsey & 11.9 .1889 & Pt Chambers & 1.10 .1889 & $\begin{array}{l}\text { East, north \& } \\
\text { northwest coasts }\end{array}$ & Pt Chambers & 27.12 .1889 & 10 tuns & \\
\hline Awarua & 29.11 .1889 & Invercargil & 6.12 .1889 & $\begin{array}{l}\text { Isthmus \& } \\
\text { Lusitania Bay }\end{array}$ & 25.12 .1889 & & & 35 tuns \\
\hline Awarua & & & 20.4 .1890 & Lusitania Bay? & 1.5 .1890 & Invercargil & 12. 5.1890 & 3 tuns penguin oil \\
\hline
\end{tabular}




\begin{tabular}{|c|c|c|c|c|c|c|c|c|}
\hline Vessel & $\begin{array}{l}\text { Departure } \\
\text { Date }\end{array}$ & $\begin{array}{c}\text { Port } \\
\text { Departure }\end{array}$ & $\begin{array}{c}\text { Arrival } \\
\text { Date }\end{array}$ & Region & $\begin{array}{c}\text { Departure } \\
\text { Date }\end{array}$ & $\begin{array}{c}\text { Port } \\
\text { Return }\end{array}$ & $\begin{array}{l}\text { Return } \\
\text { Date }\end{array}$ & Cargo \\
\hline Kakanui & 24.12 .1890 & Invercargil & 2. 1.1891 & Lusitania Bay & 2. 1.1891 & & & $\begin{array}{l}18-20 \text { tuns elephant } \& \\
\text { penguin oil }\end{array}$ \\
\hline $\begin{array}{l}\text { Gratitude } \\
\text { Hinemoa } \\
\text { Gratitude }\end{array}$ & $\begin{array}{r}15.1 .1891 \\
22.1 .1891 \\
? .10 .1891\end{array}$ & $\begin{array}{l}\text { Invercargil } \\
\text { Invercargil }\end{array}$ & $\begin{array}{r}2.2 .1891 \\
29.1 .1891\end{array}$ & & & $\begin{array}{l}\text { Invercargil } \\
\text { Invercargil } \\
\text { Invercargil }\end{array}$ & $\begin{array}{r}18.3 .1891 \\
6.2 .1891 \\
18.12 .1891\end{array}$ & $\begin{array}{l}? \\
0 ? \\
\text { Penguin oil }\end{array}$ \\
\hline $\begin{array}{l}\text { Gratitude } \\
\text { Gratitude } \\
\text { Gratitude } \\
\text { Gratitude }\end{array}$ & $\begin{array}{r}2.4 .1893 \\
5.8 .1893 \\
14.12 .1893\end{array}$ & $\begin{array}{l}\text { Invercargil } \\
\text { Invercargil }\end{array}$ & $\begin{array}{r}9.1 .1893 \\
23.4 .1893 \\
25.8 .1893 \\
17.12 .1893\end{array}$ & $\begin{array}{l}\text { Nuggets } \\
\text { Lusitania Bay }\end{array}$ & $\begin{array}{r}12.9 .1893 \\
28.12 .1893\end{array}$ & $\begin{array}{l}\text { Invercargil } \\
\text { Invercargil }\end{array}$ & $\begin{array}{r}21.9 .1893 \\
2.1 .1894\end{array}$ & $\begin{array}{l}17 \text { tuns penguin oil } \\
30 \text { tuns penguin oil } \\
\text { "Cargo of oil" } \\
\text { "Cargo of oil" }\end{array}$ \\
\hline $\begin{array}{l}\text { Gratitude } \\
\text { Gratitude } \\
\text { Gratitude } \\
\text { Antarctic } \\
\text { Gratitude }\end{array}$ & $\begin{array}{r}22.2 .1894 \\
10.5 .1894 \\
26.8 .1894 \\
3.10 .1894 \\
6.12 .1894\end{array}$ & $\begin{array}{l}\text { Invercargil } \\
\text { Invercargil } \\
\text { Hobart }\end{array}$ & $\begin{array}{l}11.3 .1894 \\
26.5 .1894 \\
\\
20.10 .1894 \\
31.12 .1894\end{array}$ & $\begin{array}{l}\text { Nuggets } \\
\text { Via Auckland Is? } \\
\text { Could not land }\end{array}$ & $\begin{array}{r}23.3 .1894 \\
3.6 .1894\end{array}$ & Invercargil & $\begin{array}{r}31.3 .1894 \\
1.11 .1894\end{array}$ & $\begin{array}{l}\text { Penguin oil? } \\
\text { "Cargo of oil" } \\
24 \text { casks blubber, } 500 \text { skins } \\
\text { Skins only }\end{array}$ \\
\hline $\begin{array}{l}\text { Gratitude } \\
\text { Gratitude }\end{array}$ & $\begin{array}{l}13.2 .1895 \\
26.8 .1895\end{array}$ & $\begin{array}{l}\text { Invercargil } \\
\text { Invercargil }\end{array}$ & 25. 9.1895 & & 3.10 .1895 & Invercargil & 31.3 .1895 & $\begin{array}{l}269 \text { casks penguin oil } \\
?\end{array}$ \\
\hline Gratitude & 1. 1.1896 & Invercargil & 13. 1.1896 & & 12.2 .1896 & & & $\begin{array}{l}60 \text { tuns elephant \& } \\
\text { penguin oil }\end{array}$ \\
\hline $\begin{array}{l}\text { Gratitude } \\
\text { Gratitude }\end{array}$ & $\begin{array}{r}19.9 .1896 \\
2.11 .1896\end{array}$ & Invercargil & $\begin{array}{l}11.10 .1896 \\
28.11 .1896\end{array}$ & & 28.10 .1896 & Invercargil & $\begin{array}{r}1.11 .1896 \\
31.12 .1896\end{array}$ & $\begin{array}{l}35 \text { tuns left } \\
30 \text { tuns oil }\end{array}$ \\
\hline $\begin{array}{l}\text { Gratitude } \\
\text { Gratitude } \\
\text { Gratitude } \\
\text { Gratitude }\end{array}$ & $\begin{array}{r}23.1 .1897 \\
23.3 .1897 \\
26.8 .1897 \\
23.12 .1987\end{array}$ & $\begin{array}{l}\text { Invercargil } \\
\text { Melbourne } \\
\text { New River } \\
\text { Invercargil }\end{array}$ & $\begin{array}{l}6.9 .1897 \\
3.1 .1898\end{array}$ & Lusitania Bay & $\begin{array}{r}20.4 .1897 \\
9.1 .1898\end{array}$ & $\begin{array}{l}\text { Melbourne } \\
\text { Pt Chambers } \\
\text { Invercargil } \\
\text { Invercargil }\end{array}$ & $\begin{array}{r}9.3 .1897 \\
24.4 .1897 \\
13.12 .1897 \\
26.1 .1898\end{array}$ & $\begin{array}{l}54 \text { tuns oil } \\
\text { "Cargo of oil" } \\
0 \\
20 \text { tuns oil }\end{array}$ \\
\hline $\begin{array}{l}\text { Gratitude } \\
\text { Gratitude } \\
\text { Gratitude }\end{array}$ & $\begin{array}{r}28.2 .1898 \\
29.4 .1898 \\
11.10 .1898\end{array}$ & $\begin{array}{l}\text { Invercargil } \\
\text { Invercargil }\end{array}$ & $\begin{array}{r}11.3 .1898 \\
22.5 .1898 \\
28.10 .1898\end{array}$ & $\begin{array}{l}\text { Nuggets } \\
\text { Nuggets-beached }\end{array}$ & $\begin{array}{l}1.4 .1898 \\
8.6 .1898\end{array}$ & Pt Chambers & 14.4 .1898 & $\begin{array}{l}\text { "Cargo of oil" } \\
\text { "Cargo of oil" }\end{array}$ \\
\hline
\end{tabular}




\begin{tabular}{|c|c|c|c|c|c|c|}
\hline $\begin{array}{l}\text { Carin } \\
\text { Hinemoa } \\
\text { H M Ringdove }\end{array}$ & $\begin{array}{r}17.2 .1900 \\
7.4 .1900\end{array}$ & $\begin{array}{l}\text { Launceston } \\
\text { Invercargil }\end{array}$ & $? .12 .1900$ & Unable to land & & \\
\hline Discovery & & & 22.11 .1901 & & & \\
\hline $\begin{array}{l}\text { Tutanekai } \\
\text { Enterprise } \\
\text { Enterprise }\end{array}$ & $\begin{array}{r}3.9 .1902 \\
24.12 .1902\end{array}$ & $\begin{array}{l}\text { Otago } \\
\text { Pt Chambers }\end{array}$ & $\begin{array}{l}13.1 .1902 \\
12.9 .1902\end{array}$ & Could not land & 21.10 .1902 & $\begin{array}{l}\text { Pt Chambers } \\
\text { Pt Chambers }\end{array}$ \\
\hline Enterprise & 18. 4.1903 & Dunedin & 9.5 .1903 & Nuggets & & Otago \\
\hline $\begin{array}{l}\text { Jessie Nichols } \\
\text { Jessie Nichols }\end{array}$ & $\begin{array}{r}4.9 .1905 \\
4.12 .1905\end{array}$ & Pt Chambers & 13. 9.1905 & & & $\begin{array}{l}\text { Pt Chamber } \\
\text { Invercargil }\end{array}$ \\
\hline Jessie Nichols & ?. 2.1906 & & ?. 8.1906 & & & \\
\hline Jessie Nichols & 12.8.1907 & Dunedin & 27.8 .1907 & & 18. 9.1907 & Invercargil \\
\hline $\begin{array}{l}\text { Jessie Nichols } \\
\text { Jessie Nichols } \\
\text { Jessie Nichols }\end{array}$ & $\begin{array}{r}11.11 .1907 \\
3.2 .1908 \\
30.11 .1908\end{array}$ & $\begin{array}{l}\text { Invercargil } \\
\text { Invercargil }\end{array}$ & 16.12 .1908 & Nuggets & 6. 1.1909 & New River \\
\hline $\begin{array}{l}\text { Jessie Nichols } \\
\text { Nimrod } \\
\text { Jessie Nichols } \\
\text { Jessie Nichols } \\
\text { Jessie Nichols }\end{array}$ & 24. 9.1909 & & $\begin{array}{r}25.5 .1909 \\
9.8 .1909 \\
\\
10.12 .1909\end{array}$ & & $\begin{array}{l}17.3 .1909 \\
30.5 .1909 \\
21.8 .1909\end{array}$ & \\
\hline $\begin{array}{l}\text { Jessie Nichols } \\
\text { Jessie Nichols }\end{array}$ & $\begin{array}{r}20.1 .1910 \\
8.3 .1910\end{array}$ & Invercargil & 8. 2.1910 & $\begin{array}{l}\text { Unable to reach } \\
\text { Macquarie Is }\end{array}$ & 12. 2.1910 & Invercargil \\
\hline $\begin{array}{l}\text { Hinemoa } \\
\text { Jessie Nichols }\end{array}$ & $\begin{array}{l}22.7 .1910 \\
18.8 .1910\end{array}$ & Invercargil & 25.7 .1910 & Nuggets & & \\
\hline Jessie Nichols & 8.12 .1910 & Invercargil & 18.12 .1910 & $\begin{array}{l}\text { Wrecked } \\
\text { Sandy Bay }\end{array}$ & & \\
\hline $\begin{array}{l}\text { Ida M. Clarke } \\
\text { Huanui }\end{array}$ & 11.3 .1911 & Invercargil & early 1911 & & & \\
\hline Clyde & 28. 9.1911 & Wellington & & $\begin{array}{l}\text { Wrecked } \\
\text { Buckles Bay }\end{array}$ & & \\
\hline $\begin{array}{l}\text { Toroa } \\
\text { Aurora } \\
\text { Toroal }\end{array}$ & 9.12 .1911 & Hobart & $\begin{array}{r}11.12 .1911 \\
3.12 .1911\end{array}$ & & 23.12 .1911 & \\
\hline
\end{tabular}

27. 4.1900 "Cargo of oil"

27. 4.19000

0

40 tuns oil

$28.11 .1902 \quad 0$

17. $2.1903 \quad 0$

30. 5.190360 tuns oil

14.10.1905 0

28.12.1905 Penguin oil

3. 9.190650 tuns oil

7.10 .190753 casks oil

13.12.1907?

6. 3.1908306 casks oil

$\begin{array}{rl} & 56 \text { tuns oil } \\ & 0 \\ 3.9 .1909 & 0 ? \\ 3.11 .1909 & \text { "Cargo of oil" } \\ 27.12 .1909 & \text { "Cargo of oil" }\end{array}$

18. 2.1910 ?

0

28. 7.1910 Oil from 675 elephant seals 19.10.1910

0

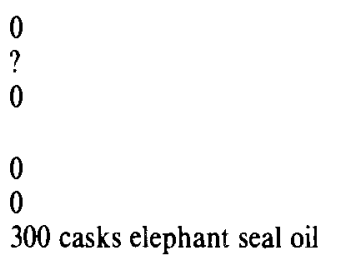




\begin{tabular}{|c|c|c|c|c|c|c|c|c|}
\hline Vessel & $\begin{array}{c}\text { Departure } \\
\text { Date }\end{array}$ & $\begin{array}{c}\text { Port } \\
\text { Departure }\end{array}$ & $\begin{array}{c}\text { Arrival } \\
\text { Date }\end{array}$ & Region & $\begin{array}{l}\text { Departure } \\
\text { Date }\end{array}$ & $\begin{array}{c}\text { Port } \\
\text { Return }\end{array}$ & $\begin{array}{c}\text { Return } \\
\text { Date }\end{array}$ & Cargo \\
\hline $\begin{array}{l}\text { Aurora } \\
\text { Rachel Cohen } \\
\text { Aurora } \\
\text { Rachel Cohen }\end{array}$ & $\begin{array}{r}17.5 .1912 \\
1.9 .1912\end{array}$ & Hobart & $\begin{array}{r}6.7 .1912 \\
8.9 .1912 \\
2.11 .1912 \\
2.1 .1913\end{array}$ & & $\begin{array}{r}8.10 .1912 \\
25.11 .1912 \\
5.2 .1913\end{array}$ & Hobart & 1. 3.1913 & $\begin{array}{l}0 \\
\text { I16 barrels elephant seal oil } \\
? \\
216 \text { barrels penguin oil }\end{array}$ \\
\hline Rachel Cohen & 5. 7.1913 & Hobart & & $\begin{array}{l}\text { Unable to reach } \\
\text { Macquarie Island }\end{array}$ & & & & 0 \\
\hline $\begin{array}{l}\text { Tutanekai } \\
\text { Rachel Cohen } \\
\text { Aurora } \\
\text { Rachel Cohen }\end{array}$ & $\begin{array}{l}28.10 .1913 \\
19.11 .1913 \\
30.12 .1913\end{array}$ & $\begin{array}{l}\text { Dunedin } \\
\text { Hobart } \\
\text { Hobart? }\end{array}$ & $\begin{array}{r}20.8 .1913 \\
8.11 .1913 \\
28.11 .1913\end{array}$ & & $\begin{array}{r}22.8 .1913 \\
28.11 .1913 \\
21.1 .1914\end{array}$ & $\begin{array}{l}\text { Hobart } \\
\text { Hobart }\end{array}$ & $\begin{array}{r}14.12 .1913 \\
4.2 .1914\end{array}$ & $\begin{array}{l}0 \\
460 \text { casks oil } \\
0 \\
420 \text { barrels oil }\end{array}$ \\
\hline $\begin{array}{l}\text { Rachel Cohen } \\
\text { Endeavour } \\
\text { Aurora }\end{array}$ & $\begin{array}{l}25.11 .1914 \\
25.12 .1914\end{array}$ & $\begin{array}{l}\text { Hobart } \\
\text { Hobart }\end{array}$ & $\begin{array}{r}? .11 .1914 \\
29.11 .1914 \\
30.12 .1914\end{array}$ & & $\begin{array}{r}3.12 .1914 \\
31.12 .1914\end{array}$ & Pt Chambers & 4.11 .1914 & $\begin{array}{l}\text { "Oil and skins" } \\
0 \\
0\end{array}$ \\
\hline $\begin{array}{l}\text { Grantala } \\
\text { Rachel Cohen }\end{array}$ & $? .10 .1914$ & Dunedin & $\begin{array}{r}7.1 .1915 \\
29.11 .1915\end{array}$ & & $? .1 .1915$ & $\begin{array}{l}\text { Hobart } \\
\text { Invercargil }\end{array}$ & $\begin{array}{l}18.8 .1915 \\
13.12 .1915\end{array}$ & $\begin{array}{l}0 \\
43 \text { barrels oil }\end{array}$ \\
\hline $\begin{array}{l}\text { Rachel Cohen } \\
\text { Rachel Cohen } \\
\text { Rachel Cohen } \\
\text { Rachel Cohen }\end{array}$ & $\begin{array}{r}30.1 .1916 \\
27.5 .1916 \\
26.9 .1916 \\
9.12 .1916\end{array}$ & $\begin{array}{l}\text { Invercargil } \\
\text { Invercargil } \\
\text { Invercargil }\end{array}$ & $\begin{array}{r}5.6 .1916 \\
10.10 .1916 \\
31.12 .1916\end{array}$ & & $\begin{array}{r}29.10 .1916 \\
12.1 .1917\end{array}$ & $\begin{array}{l}\text { Invercargil } \\
\text { Invercargil } \\
\text { Invercargil } \\
\text { Hobart }\end{array}$ & $\begin{array}{r}29.2 .1916 \\
5.7 .1916 \\
4.11 .1916 \\
2.2 .1917\end{array}$ & $\begin{array}{l}? \\
0 \\
3.5 \text { tuns oil } \\
470 \text { barrels oil }\end{array}$ \\
\hline $\begin{array}{l}\text { Rachel Cohen } \\
\text { Rachel Cohen } \\
\text { Rachel Cohen }\end{array}$ & $\begin{array}{r}30.10 .1917 \\
11.7 .1917 \\
19.12 .1917\end{array}$ & $\begin{array}{l}\text { Hobart } \\
\text { Invercargil } \\
\text { Hobart }\end{array}$ & 25.12 .1917 & & $\begin{array}{l}16.11 .1917 \\
22.12 .1917\end{array}$ & Hobart & 1.12 .1917 & $\begin{array}{l}216 \text { barrels oil } \\
? \\
?\end{array}$ \\
\hline $\begin{array}{l}\text { Rachel Cohen } \\
\text { Tutanekai }\end{array}$ & 22. 1.1918 & Invercargil & $\begin{array}{r}8.2 .1918 \\
28.4 .1918\end{array}$ & & 10.5 .1918 & & & $\begin{array}{l}299 \text { casks elephant oil? } \\
?\end{array}$ \\
\hline $\begin{array}{l}\text { Rachel Cohen } \\
\text { Rachel Cohen }\end{array}$ & $\begin{array}{r}19.9 .1918 \\
10.12 .1918\end{array}$ & $\begin{array}{l}\text { Invercargil } \\
\text { Hobart }\end{array}$ & 9.10 .1918 & Nuggets & 2.11 .1918 & $\begin{array}{l}\text { Hobart } \\
\text { Hobart }\end{array}$ & $\begin{array}{r}19.11 .1918 \\
30.1 .1919\end{array}$ & $\begin{array}{l}486 \text { casks penguin oil } \\
550 \text { barrels elephant }\end{array}$ \\
\hline Rachel Cohen & 1. 4.1919 & & & & & Invercargil & & 450 casks oil \\
\hline
\end{tabular}

